DOI: https://doi.org/10.32839/2304-5809/2021-3-91-16

УДК 811.111'367.32'42:821.111(73)-3

Томусяк А.О., Томусяк Л.М.

Чернівецький національний університет імені Юрія Федьковича

\title{
ПОЛІПАРАДИГМАЛЬНА ПРИРОДА ХУДОЖНЬОГО ТЕКСТУ В СУЧАСНИХ НАУКОВИХ РОЗВІДКАХ
}

\begin{abstract}
Анотація. Статтю присвячено з'ясуванню поліпарадигмальної природи художнього тексту та ролі людського чинника в сучасній лінгвістиці. Виявлено антропоцентричні тенденції, що домінують у сучасних дослідженнях тексту та відображено різноманітні підходи до тексту (семіотичний, лінгвістичний, комунікативний, когнітивний, прагматичний). Проаналізувано текст як комунікативний акт та виділено чотири аспекти при вивченні тексту - екстралінгвальний, когнітивний, семантичний і лінгвістичний. Розглянуто художній текст як авторський потік свідомості, зафріксований у мовній фрормі, яка відображає авторську позицію, його світобачення, погляди, міркування, емоції, оцінки, тобто його мовостиль. З'ясовано, що образ автора об'єднуе всі елементи змісту і стилю художнього твору в текстове ціле.
\end{abstract}

Ключові слова: поліпарадигмальність, антропоцентризм, мовна особистість, семіотичність, вербальність.

Tomusiak Alina, Tomusiak Liudmyla

Yuriy Fedkovych Chernivtsi National University

\section{POLYPARADIGMAL NATURE OF LITERARY TEXT IN MODERN SCIENTIFIC STUDY}

Summary. The article is devoted to elucidating the polyparadigmatic nature of the literary text and the role of the human factor in modern linguistics. Anthropocentric tendencies that dominate in modern research of the text are revealed and various approaches to the text (semiotic, linguistic, communicative, cognitive, pragmatic) are reflected. The text as a communicative act is analyzed and four aspects of text study are singled out - extralingual, cognitive, semantic and linguistic. The literary text is considered as the author's stream of consciousness, fixed in the linguistic form, which reflects the author's position, his worldview, views, opinions, emotions, evaluations, ie his style. It is found that the image of the author combines all the elements of content and style of the literary text into a textual unit. The concepts of linguistic personality, picture of the human world, the author of the message and his intentions are key in the paradigm of scientific research, including the analysis of literary texts. These categories remain unclear and are the subject of linguistic analysis. Anthropocentrism as one of the leading episteme of modern humanities knowledge, the methodological principle of research is widely used in the analysis of language as a product of human activity, and the literary text is such a product of creative personality. The study of the human factor meets the objectives of the analysis of the literary text, as it aims to reveal the nature of the creative, to establish a combination of stereotype and new, to define the boundaries of possible innovations and describe the origins of linguistic and creative thinking. Anthropocentric tendencies that dominate in modern text research include the development of ideas for reviving interest in the problem of the author's image and authorial intentions, a description of the author's picture of the world, because there is no text that is not generated by the communicative intentions of the speaker. The concepts of linguistic personality, the polyparadigmatic nature of the literary text remain the key in modern scientific studies.

Keywords: polyparadigm, anthropocentrism, linguistic personality, semiotics, verbality.

Постановка проблеми. Значне місце в сучасній парадигмі наукових знань посідають дослідження закономірностей осмислення людиною дійсності та принципів передачі отриманого досвіду засобами мови. Ситуацію в лінгвістищі сьогодення дослідники визначають як поліпарадигмальну, тобто таку, що відмовляеться від ідеї винятковості того чи іншого підходу, а поєднує різні методи й підходи 3 огляду на аспектуальність дослідження. У рамках ціеї парадигми співіснуе щіла низка концепцій, що перебувають у постійній взаємодії й внаслідок цьго збагачують одна одну.

Сучасна лінгвістика перейшла від вивчення мови як самодостатньої системи (мови „в собі й для себе") до її вивчення в тісному зв'язку

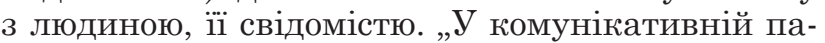
радигмі знань мову досліджують з огляду на ї̈ роль в реальному мовленні, де на перше місце виходить мовна особистість та їі дискурсна діяльність", - зауважуе I. А. Бехта [2, с. 11]. Такий перехід пов'язаний 3 антропоцентризмом сучасної наукової парадигми. Антропоцентризм у лінгвістиці сягає корінням лінгвофрілософрської концепції В. фрон Гумбольдта „людина в мові”, у якій закцентовано на здатності мови фрормувати й виражати людську особистість. Досліджуючи фрундаментальну проблему співвідношення мислення та мови, вчений наголосив на тому, що мова - процес творення думки, мислення, мова це „світ, що лежить між світом зовнішніх явищ і внутрішнім світом людини” [5, с. 304].

Аналіз останніх досліджень i публікацій. Незважаючи на те, що антропоцентричний принцип із визнанням людини є центральним поняттям різноманітних наукових гуманітарних напрямів досліджень (як-от: когнітивної лінгвістики, психолінгвістики, соціолінгвістики, етнолінгвістики, прагматики, лінгвістичної гендерології та ін.), поняття антропоцентризм не отримало однозначного потрактування. Антропоцентризм розуміють „і як категорію онтологічну, що відображає буття людини в мові й мови в людині, і як „форомальну репрезентацію знань про людину в мові”, адже в центрі всього зображуваного словом стоїть людина - вона сама й усе те, що нею сприйняте як її оточення, сорера ії буття, і як категорію методологічну (,антропоцентризм - ме- 
тодологічна база сучасної наукової парадигми”) (О. Кубрякова), зокрема й як підхід до мови 3 позицій носія мови 3 погляду його лінгвістичної інтуїції (системоцентричне та інтуїтивне вивчення мови у розумінні В. Алпатова)" [11, с. 109].

У межах надзвичайно широкого діапазону досліджень, які грунтуються на антропоцентризмі, спостерігаємо скерування на вивчення ролі людини в мові, з одного боку, та мови, призначеної для задоволення комунікативних потреб людини, з іншого. Це зумовлено не тільки увагою до людського чинника й суб'єктивності у лінгвістиці, але й унікальним статусом мови як об'єкта й одночасно інструмента дослідження. Функціонування мовних одиниць дедалі частіше прив'язують до носія мови - людини, тобто предметом уваги є мотивованість мовної системи та їі використання в мовленні. Зокрема, М. О. Шелякін зазначае, що під поняттям мотивованості мовної системи розуміють те, що мовна система перебуває у прямій залежності від людських потреб, соціального й індивідуального досвіду [12, с. 14]. Як бачимо, антропоцентризм у цьому випадку полягає в тому, що предмет дослідження тісно пов'язаний із його роллю в житті людини, з його місцем у їі життедіяльності. О. Ю. Кущева виокремила такі чотири напрями сучасних антропоцентричних пошуків, як: 1) дослідження мовної картини світу; 2) комунікативна лінгвістика; 3) когнітивна лінгвістика; 4) внутрішньосуб'єктна лінгвістика (теорія мовної особистості, лінгвоперсонологія) [9, с. 155-156]. Усі вони спрямовані на визначення „окремих фрагментів образу людини в антропоцентричній системі мови і просторі культури" [11, с. 109]. Комунікативно-прагматична лінгвістика спрямовуе свої дослідження на аналіз мовних засобів у тісному зв'язку з мовцем - суб'єктом мовленнєвої комунікації. Користувач мови вживає такі мовні стереотипи, які органічні його світогляду.

Невирішені проблемні питання. Поняття мовної особистості, картини світу людини, автора повідомлення та його інтенцій $є$ ключовими в парадигмі наукових розвідок, у тому числі й аналізу художнього тексту. Ці категорії залишаються не до кінця з'ясованими і є предметом лінгвістичного аналізу.

Мета статті - з'ясувати мотиваційну сдеру мовної особистості автора та довести поліпарадигмальну спрямованість сучасних наукових досліджень художнього тексту.

Виклад основного матеріалу дослідження. Антропоцентризм як одну із провідних епістем сучасного гуманітарного знання, методологічний принцип дослідження широко використовують при аналізі мови як продукту людської діяльності, а художній текст і є таким „Продуктом” творчої особистості.

Дослідження людського фрактора відповідає завданням аналізу художнього тексту, оскільки ставить перед собою мету - відкрити природу творчого, встановити поєднання стереотипного і нового, визначити межі можливих інновацій та описати витоки лінгвокреативного мислення, адже антропоцентризм у художньому тексті визначають як „категорію, зумовлену сукупністю здібностей і характеристик людини створювати та сприймати мовленнєві витвори (тексти)” [6, с. 246].
До антропоцентричних тенденщій, що домінують у сучасних дослідженнях тексту, належить розробка ідей відродження інтересу до проблеми образу автора та авторських інтенцій, опис авторської картини світу, адже „немає жодного тексту, який би не був породжений комунікативними намірами суб'єкта мовлення, який би не відображав у своїй структурі ту чи іншу авторську позицію у відношенні до повідомлюваного" [4, с. 37]. Текст дає вихідний матеріал досліднику мови. Відомо, що людина у своєму мовленні оперує текстами, а не окремими словами чи реченнями. Але текст - явище настільки багатогранне й різнопланове, що не існуе і навряд чи може існувати його едине розуміння й тлумачення. Кожен дослідник відображає в понятті „текст” власне бачення проблеми й по-своєму його трактує залежно від тієї галузі знань, якою він займається, і відповідно до своїх наукових поглядів та своєї концепції й розуміння природи мови і людини.

Різноманітні підходи до тексту (семіотичний, лінгвістичний, комунікативний, когнітивний, прагматичний) пов'язані з відмінностями у виявленні тих його характеристик, які дослідник визнає обов'язковими. Зокрема, Ю. М. Лотман, називаючи необхідною характеристикою тексту його семіотичність, виявляе семіотичні об'єкти в усіх видах мистецтв. Побудовані за типом мов, такі об’єкти, на думку вченого, $є$ „вторинними моделювальними системами. Якщо мистецтво може бути описане як якась вторинна мова, то твір мистецтва - як текст, створений цією мовою” [10, с. 16].

Вербальність тексту як його обов'язкова характеристика виводить текст за межі письмового повідомлення й змушуе віднести до нього й усні, спонтанні висловлювання. Текст, таким чином, зводиться до „зафріксованого в мовній формі” повідомлення. Ф. С. Бацевич, аналізуючи також текст з погляду комунікативного, тлумачить його як „результат спілкування (інтеракції та трансакщіі), його структурно-мовна складова і одночасно кінцева реалізація; структура, в яку втілюеться „живий” дискурс після його завершення” [1, с. 147]. Учений зазначає, що текст „як лінгвістичне явище характеризуеться такими ознаками: зв'язністю, цілісністю, інтенційністю (авторською метою), інформативністю, ситуативністю (зв'язністю з контекстом), членованістю, інтегративністю, модальністю (особистісним ставленням), розгорнутістю ... тощо" [Там само].

На відміну від суто лінгвістичного підходу комунікативно-прагматичний підхід до тексту акцентуе увагу на мовній особистості комунікантів, їх мовленневій взаємодії й передбачає врахування соціальних, когнітивних, ситуативних та інших чинників комунікації. Такий підхід, на нашу думку, є плідним при дослідженні тексту як необхідного складника дискурсу автора, при аналізі авторської і читацької картин світу, представлених у тексті.

В. В. Красних, аналізуючи текст як комунікативний акт, виділяе чотири аспекти, які, на іï думку, повинні бути враховані при вивченні тексту - екстралінгвальний, когнітивний, семантичний і лінгвістичний. Те, що текст є реакцією на ситуацію, одним із компонентів якої є конситуація, тобто власне екстралінгвістична реальність, становить екстралінгвальний аспект вивчення 
тексту. Когнітивний аспект передбачає наявність широкої пресупозиції, яка зумовлюе успішне протікання комунікації, тобто відбір адекватних засобів при породженні тексту, і його адекватне розуміння. Семантичний аспект повинен брати до уваги контекст, що впливае на відбір мовних засобів і будову тексту й обумовлюе його адекватне сприйняття. Власне лінгвістичний аспект стосується сукупності мовних засобів, які фрормують текст, вербальний продукт [8, с. 199].

Актуальність комунікативного напрямку вивчення тексту визначається антропоцентризмом як однією 3 домінуючих характеристик сучасної наукової парадигми, суб'єктний характер якої з усією очевидністю заявляе про себе в художньому тексті внаслідок його беззаперечної антропоцентричної природи.

Художній текст, як і будь-який інший текст, e центральним компонентом системи „адресант - текст - адресат", специфіка якої в мистецькій сфері спілкування обумовлена прагненням автора впливати на емоційне, чутливе сприйняття написаного читачем. При описі мовних одиниць 3 погляду комунікативно-прагматичного підходу найбільш важливими є два аспекти визначення мовної поведінки, пов'язаної: 1) з вибором мовних засобів для ефективного досягнення комунікативної мети; 2) зі ставленням автора до дійсності, до того, про що він говорить.

Антропоцентричність художнього тексту проявляеться й у взаемодії „автор - читач”. І. А. Бехта, дослідник англомовного художнього тексту XX століття, зауважуе, що „адресованість властива тексту загалом. Утім, вона не задаеться апріорно, а формуеться відповідно до текстового розгортання і виявляеться за сигналами у тканині тексту. Одним із таких сигналів е точка зору адресата..." [2, с. 97]. Читач - учасник реального діалогу з письменником - $е$ невід'ємною частиною художньої структури літературного твору, його завершальною ланкою.

У художньому тексті наявні всі особливості, властиві тексту загалом, однак є і специфічні ознаки, що відрізняють його від нехудожніх текстів. Назвемо ці специфічні ознаки. Художній текст ,формуеться (перебуваючи в постійному процесі становлення) як онтологічно відкрита величина: він звільняеться від конвенційних форм стереотипної закріпленості, відкриваючи в собі реляційно-смислові парадигми, нове дистанціювання поверхневих і глибинних семантичних структур, що може спричинювати зміну текстуальних i міжтекстових перспектив, викликати зміщення диспозиційних властивостей оприявленого референта" [3, с. 326].

Смислова відкритість $є$ важливою характеристикою художнього тексту. Його ускладнена структура, витворена мовним матеріалом, дозволяе передавати набагато більший обсяг інформації. „Генерування нових смислів - домінантний аспект тієї роботи, яку виконуе художній текст у системі культури", - вважає Ю. М. Лотман [10, с. 99]. Художній текст часто концентруе містку інформацію у „площині” невеликого тексту й „видає різним читачам" неоднакову інформацію - кожному за його розумінням. У зв'язку з цим Ю. М. Лотман зазначае: „Він пропонуе читачеві мову, якою можна засвоїти певний обсяг відомостей при перечи- туванні, і поводиться як „живий організм”, що перебувае в зворотньому зв'язку з читачем і навчае цього читача" [10, с. 29-33].

Художній текст $є$ носіем ідейно-естетичної інформації, результатом естетичного освоення зображуваної дійсності відповідно до авторського задуму. Здатність передавати естетичну інформацію е визначальним моментом організації художнього тексту. Сукупність художнього тесту це сукупність естетичних мовленневих актів, які репрезентують певний зміст авторської картини світу. У процесі естетичного сприйняття актуалізуються взаємовідношення елементів естетичного об'єкта і його відношення до інших об'єктів. Оскільки естетичне сприйняття пов'язане 3 індивідуальними особливостями психіки людини, воно е процесом суб’ективним, але об’ективно обумовленим.

Естетична інформація, зображально-виражальна фрункщія, метафоричність, семантична емність унаслідок конотативних значень детермінують експресивно-образну організацію художнього тексту як вираження категорії образності. Прийоми й правила вживання і поеднання конкретних мовних засобів, у тому числі елементів образності, залежать від стилю твору в цілому, основою якого є „образ автора”. Будьякі стилістичні засоби експресивності мають емоційне або оцінне навантаження. Нерідко навіть нейтральні у стилістичному плані мовні засоби можуть набувати експресивного значення.

Художній текст $е$, звісно, предметом найрізноманітніших літературознавчих студій, де його розглядають як авторський потік свідомості, зафріксований у мовній формі, яка відображає авторську позицію, його світобачення, погляди, міркування, емоції, оцінки, тобто його мовостиль.

Сучасна наукова парадигма, пов'язана з людським фактором, визначае актуальність багатоаспектного дослідження параметру „автор”: автор - це провідний антропоцентр, суб̆єкт, мовна особистість, що тісно переплетена з особистістю читача як адресата „художнього” продукту.

I. А. Бехта у своїй монографічній праці акцентуе ще на одній дуже важливій і суттевій властивості художнього тексту - „концептуальній категорії автор-наратор і персонаж, які взаемодіють у літературному творі та в художній дійсності тексту. Ці феномени мають статус провідних смислових категорій художнього тексту, бо відображають найзагальніші, суттеві, системні властивості та закономірності художньої комунікації засобами мови" [2, с. 15]. Безперечно, персонаж (як і вся система образів, весь текст загалом) - це віддзеркалення авторського інтенщійного обширу.

А. Б. Кошляк виділяе категорії художнього тексту, які репрезентують його як певну стилістичну систему і можуть бути одиницями стилістичного аналізу художнього тексту: „образ автора” і „підтекст”. „Образ автора” - це суб’єкт оповіді, який сам творить дійсність, це зумисне вибрана письменником позиція, де він отримуе найкращі можливості для втілення ідейного задуму свого твору” [7, с. 44]. „Образ автора” об'єднуе всі елементи змісту і стилю художнього твору в текстове ціле. Автор визначає манеру і структуру оповіді, відбір лексики і синтаксичних структур, способи характеристики дійових 
осіб, зображення пейзажу тощо, тобто сюжет і об-

рази героїв породжуються автором.

Висновки 3 дослідження і перспективи подальших пошуків у даному науковому напрямку. Отже, поняття мовної особистості, поліпарадигмальної природи художнього тексту залишаються ключовими в сучасних наукових розвідках. В цьому ми вбачаємо актуальність i перспективу в подальших наукових пошуках у контексті аналізу художнього тексту.

\section{Список літератури:}

1. Бацевич Ф. С. Основи комунікативної лінгвістики : Підручник. Київ : ВЦ «Академія», 2004. 344 с.

2. Бехта I. А. Авторське експериментаторство в англомовній прозі XX століття. Львів : ПАIC, 2013.268 с.

3. Голянич М. І., Іванишин Н. Я., Ріжко Р. Л., Стефурак Р. І. Лінгвістичний аналіз тексту: словник термінів. Івано-Франківськ : Сімик, 2012. 392 с.

4. Гуйванюк Н. В. Слово - Речення - Текст : Вибр. праці. Чернівці : Чернівецький нац. ун-т, 2009.664 с.

5. Гумбольдт В. Избранные труды по языкознанию / Пер. с нем. Москва : ОАО ИГ «Прогресс», 2001. 400 с.

6. Жирмунский В. М. Теория литературы. Поэтика. Стилистика : Избранные труды. Ленинград : Наука, 1977. 407 с.

7. Кошляк А. Б. Категории художественного текста. Стилистика текста: языковые средства экспрессивного текста. Уфра : Изд-во БГУ, 1989. С. 47-54.

8. Красных В. В. Виртуальная реальность и реальная виртуальность. Москва : Диалог-МГУ, 1998. 352 с.

9. Кущева О. Ю. Антропоцентрическая парадигма в современной лингвистике. Вестн. Адыгейского госуд. ун-та. 2006. № 4. C. 155-156.

10. Лотман Ю. М. Внутри мыслящих миров. Человек - текст - семиосфера - история. Москва : Языки русской культуры, 1996. 464 с.

11. Почепцов Г. Г. Понятие коммуникативной трансформации. Предложение и текст в семантическом аспекте : межвуз. тематич. сб. Калинин : КГУ, 1978. С. 49-63.

12. Шелякин М. А. Язык и человек: к проблеме мотивированности языковой системы. Москва : Флінта : Наука, 2005. $288 \mathrm{c}$

\section{References:}

1. Batsevych F. S. (2004) Osnovy komunikatyvnoi linhvistyky [Fundamentals of communicative linguistics]: Pidruchnyk. Kyiv, $344 \mathrm{p}$

2. Bekhta I. A. (2013) Avtorske eksperymentatorstvo v anhlomovnii prozi XX stolittia [Author's experimentation in English prose of XX century]. Lviv: PAIS, 268 p.

3. Holianych M. I., Ivanyshyn N. Ya., Rizhko R. L., Stefurak R. I. (2012) Linhvistychnyi analiz tekstu: slovnyk terminiv [Linguistic analysis of the text: a dictionary of terms]. Ivano-Frankivsk: Simyk, $392 \mathrm{p}$.

4. Huivaniuk N. V. (2009) Slovo - Rechennia - Tekst: Vybr. pratsi [Word - Sentence - Text: Select. Works]. Chernivtsi: Chernivetskyi nats. un-t, $664 \mathrm{p}$.

5. Gumbol'dt V. (2001) Izbrannye trudy po yazykoznaniyu / Per. s nem [Selected works on linguistics / Transl. from German]. Moscow: OAO IG «Progress», 400 p.

6. Zhirmunskij V. M. (1977) Teoriya literatury. Poetika. Stilistika: Izbrannye trudy [Literature theory. Poetics. Stylistics: Selected Works]. Leningrad: Nauka, 407 p.

7. Koshlyak A. B. (1989) Kategorii hudozhestvennogo teksta [Categories of literary text]. Stilistika teksta: yazykovye sredstva ekspressivnogo teksta. Ufa: Izd-vo BGU, pp. 47-54.

8. Krasnyh V. V. (1998) Virtualnaya realnost i realnaya virtualnost [Virtual reality and real virtuality]. Moscow: Dialog-MGU, $352 \mathrm{p}$.

9. Kushcheva O. Yu. (2006) Antropocentricheskaya paradigma v sovremennoj lingvistike [Anthropocentric paradigm in modern linguistics]. Vestn. Adygejskogo gosud. un-ta, no. 4, pp. 155-156.

10. Lotman Yu. M. (1996) Vnutri myslyashchih mirov. Chelovek - tekst - semiosfera - istoriya [Inside thinking worlds. Human - text - semiosphere - history]. Moscow: Yazyki russkoj kultury, $464 \mathrm{p}$.

11. Pochepcov G. G. (1978) Ponyatie kommunikativnoj transformacii. Predlozhenie i tekst v semanticheskom aspekte [The concept of communicative transformation. Sentence and text in a semantic aspect]. Kalinin: KGU, pp. 49-63.

12. Shelyakin M. A. (2005) Yazyk i chelovek: k probleme motivirovannosti yazykovoj sistemy [Language and man: to the problem of motivation of the language system]. Moscow: Flinta: Nauka, 288 p. 